\title{
RIGHT TO THE MAP? COUNTER-MAPPING PRACTICES OF SMOG ALERTS AND URBAN GREENERY MOVEMENTS IN POLAND
}

\author{
RENATA PUTKOWSKA-SMOTER ${ }^{1} \&$ JAN FRANKOWSKI ${ }^{2}$ \\ ${ }^{1}$ Polish Academy of Sciences, Institute of Philosophy and Sociology, Nowy Świat 72, 00-330 Warszawa, \\ Poland. ORCID: 0000-0002-2609-0601,Email: rputkowska@ifispan.waw.pl \\ ${ }^{2}$ Polish Academy of Sciences, Institute of Philosophy and Sociology, Nowy Świat 72, 00-330 Warszawa, \\ Poland. The Institute for Structural Research (IBS), Warszawa, Poland. ORCID: 0000-0001-9996-2952, \\ Email: jafranko@sns.edu.pl
}

ABSTRACT: Data production is becoming an emerging trend in critical urban activism. Precise and reliable public information, including spatial and environmental information, serves individual and collective 'right to the city' beliefs. One of the common strategies adopted by contemporary urban movements to ensure the accuracy and inclusiveness of urban data production processes are various forms of counter-mapping, which we introduce in this paper as a perspective aimed in critical evaluation of urban environmental conditions in Polish cities. By process tracing of smog alerts and urban greenery movements we investigate the main strategies of using such tools and their effects for both particular social actors, and general urban environmental policy. We argue that the core idea of citizen-driven collection of geographical data is strongly supported by its other features - social involvement and collective production of visualizations illustrating the scale and dynamics of particular environmental problems. In this sense, counter-mapping is aimed rather at repoliticizing urban environmental data in order to critically evaluate existing urban policy, than just to ensure greater citizen involvement in environmental decision-making.

KEYWORDS: counter-mapping, social movements, right to the city, air pollution, urban greenery 


\section{INTRODUCTION}

Maps are the basic tool of urban policy and the 'lens through which we see the city' (Dovey and Ristic 2017). Since the 1960s however, there have been critical voices challenging the so called 'power of maps' as top-down, or even oppressive, tools which underrate lay knowledge, dynamics of space, and the conflictual character of mapmaking (see Harley 1989, Rattray et al. 2015). This trend in geography flourished in various alternative socio-spatial ideas and research agendas such as critical geography (Crampton 2008) and neogeography (Turner 2006). Based on this critique, new tools and applications to collect and visualize geospatial data appeared, called citizen-driven geographic information (Lampoltshammer and Scholz 2017), Volunteered Geographic Information (VGI, Connors et al. 2012), participatory ways of using geographic information systems (GIS), or broadly, 'counter-maps'. Despite many names and some differences between those concepts, the idea is similar and can be defined as greater inclusion in mapmaking of 'non-professionals', particularly 'those outside or on the margins of large, powerful institutions such as corporations or governments' (Dalton and Stallmann 2018:95). The general aim of such initiatives is to 'add' to official maps additional, sometimes underrated, information in order to challenge (and ideally change) a dominant perception of mapped territory: 'make qualitative knowledge of places and spatial perceptions visible, for inclusion in or contestation of policy processes, thus supporting social mobilization' (Pfeffer et al. 2015). Those mapping activities are fundamentally critical to what 'the power of maps' represents by including citizen science similar to 'statactivism' (Bruno et al. 2014) or data activism (Renzi and Langlois 2015) as well as lay knowledge expertise (Harris and Hazen 2006) in state or urban decision-making.

Related literature and empirical examples pointed to several purposes/strategies of using such an approach by social actors. For instance, Elwood et al. (2012) explored a) mapping aimed at generating new geospatial data (as 'geoinformation'), b) shared geospatial data in professional and social networks (a 'geosocial' function of mapmaking), and c) visualized 'user-contributed information' (function of 'geovisualization'). Also, Crampton (2001) pointed out similar elements differentiating 'traditional' and 'new' ways of thinking about maps and the mapmaking process on the continuum from communication to visualization. He used the concept of 'cartography cubed' (MacEachren and Fraser Taylor 1994) to discuss an observed turn on three interrelated dimensions: from private to public, from low interactivity to high interactivity, and from revealing knowns to exploring unknowns. He concluded: 'Traditional cartography has emphasized public use, low interactivity, and revealing knowns, while visualization emphasizes private use, high interactivity, and exploring unknowns' (Crampton 2001: 244). As a result, the recent landscape of geographical data provision and usage gained the form of 'an assemblage of practices' (Elwood et al. 2012) which can involve various types of social actors (both formal and informal) with diverse knowledge of geographical information (lay, professional, expert in other disciplines) and differing motivations and degrees of being 'counter' or 'critical' towards dominant mapmaking. Thus, for the purpose of this article, counter-mapping has similar but not the same 
assumptions as various forms of 'participatory' GIS (see Elwood 2006, Dalton and Stallmann 2018), mainly introduced by public authorities at national or local level. Under the label of participatory GIS we understood efforts often aimed in engaging a variety of stakeholders in spatial decision-making which is already designed by actors who are in charge of such processes. Thus, they are critically focused on how to successfully incorporate varying opinions of individuals into the spatial decision-making process (Jankowski and Nyerges 2001; Simao, Densham, and Haklay 2009), and serve the role of collaborative tools to develop spatial consensus (Nyerges et al. 2006; Nikšič et al. 2017).

Instead, spontaneous counter-mapping activities (e.g. parish/sentiment/mental maps or ad hoc mapping) are unasked by any other actors but grew out of grassroots needs, anger, and interest. This critical mindset is reflected in several terms for counter-mapping in cities, such as 'autonomous cartography' (Dalton and Mason-Deese 2012), or 'guerrilla cartography' (Cowart and Powell 2019), and 'power mapping' (Maharawal and McElroy 2018). Firstly, indigenous movements were using such counter-mapping as a contestation activity against official land-use plans to extract natural resources (Peluso 1995, Kidd 2019). Then, along with the increasing availability of data collection tools (e.g. social media, map-based portals, smartphones, drones), various forms of counter-mapping has emerged in cities and has been adopted by urban movements as a tool to critically analyze urban space. They proved to meet perfectly the 'right to the city' approach. Here we are following Domaradzka's (2018: 612) interpretation of the famous Lefebvre and Harvey slogan which interestingly combines individual and collective aspects of this right as 'the individual liberty to access urban resources (including space, services, and infrastructure) and the ability to exercise collective power to reshape the processes of urbanization'. Counter-mapping can directly support both postulates through 'delineating the non-neutrality of urban environments' (Rattray 2015: 135) or 'establishing the ground truth of maps' (Taylor 2013: 9) by complementing or negating the accuracy of official ones, all motivated by involved individuals. Moreover, through its alternative approach to spatial data collection and visualization of them, counter-maps question dominating official maps and power relations behind their creation. Thanks to that, counter-mapping approaches can make visible 'the landscapes, lives, and sites of resistance and dispossession elided in capitalist, colonial, and liberal topographies’ (Maharawal and McElroy 2018: 381).

Similarly, from their very beginning Polish urban movements used various forms of citizen-driven collection of geographical data - as an information exchange platform or a channel to publicize 'right to the city' issues. They applied maps as serving both a precise analytical tool made of 'objective' layers or interactive matrix with subjective knots, paths, edges, and landmarks. Among already proposed counter-mapping activities, there were maps of spatial barriers (in Polish: mapy barier), reprivatization claims (in Polish: mapy roszczeń), or maps of craft workshops (in Polish: mapy rzemieślników) to name just a few examples. Maps used in this context served various roles from producing additional data, through ensuring greater citizen involvement in spatial decision-making to a symbolic and technical tool for critical analysis of urban policy. Using this perspective, we would like to explore why and how, despite the 
increasing popularity of using various Public Participation GIS (PP GIS) approaches among local governments (Bąkowska et al. 2016), supported by the work of research units (in Poland especially Adam Mickiewicz University research activities, see Jankowski (ed.) et al. 2018) and NGOs, spontaneous and bottom-up counter-maps are used in contemporary urban environmental politics.

Our hypothesis is that such forms of counter-mapping particularly fit in ongoing criticism about the state of urban democracy which is considered a high priority in the literature associated with critical urban theory. Scholars from this movement assert that contemporary social struggles, debates, and antagonisms are often covered by various forms of 'scientization' (Habermas 1970) or post-politics in which 'political contradictions are reduced to policy problems to be managed by experts and legitimated through participatory processes in which the scope of possible outcomes is narrowly defined in advance' (Wilson and Swyngedouw 2014: 6). Urban environmental governance is already accused of being 'post-political' (Tahvilzadeh et al. 2017, Rosol et al. 2017) and related to 'roll out environmentalism' committing to 'stronger investment (...) in the management of environmental issues and to a more entrepreneurial way of tackling those issues' (Béal 2012: 406). In this context, urban movements are seen as those which conquer an existing system (Castells 1983; Habermas 1987). For instance, Offe (1985: 820) claims that the core of social movements' efforts is to 'repoliticize' various social issues (bringing them back into political reality) using novel methods from traditional public and institutionalized politics. The aim of such efforts is to change the dominant political paradigm in a way 'to reconstitute a civil society that is no longer dependent upon (...) regulation, control, and intervention'.

It is still in question to what extent urban movements are the equivalents of such new social movements (Pickvance 2003; Jacobssen 2015; Kowalewski 2016), but for the purposes of this article, it is sufficient that all of them can be defined as social actors with a critical attitude towards urban policy. Therefore in place of the definition of urban movements, we rely on their three characteristics, proposed by Castells (1983: 328), that should appear in given collective actions jointly and clearly in opposition to the dominant logic of capitalism, technologization and statism: 1) perceive themselves as urban or civic in relation to the city; 2) their activities are local and spatially defined; and 3) mobilize around three main goals: collective consumption, cultural identity, and political self-government. The inclusive nature of the above features also appears in other definitions of urban movements and indicates their diversity in terms of a) topics discussed (e.g. quality of public space, housing, natural conditions, social participation), b) a degree of formalization (informal groups, associations, election committees) and c) the nature of the actions undertaken (one-off, cyclical, continuous). Nevertheless, grassroots counter mapping seems to share exactly the same idea of empowering citizens through new tools and unconventional solutions outside traditional urban politics (so despite public administration efforts of more participatory ways of doing such politics).

Taking into consideration the history of counter-mapping and its roots in critical evaluation of urban politics, environmental issues should be among the popular subjects of such activities. Indeed, human geography studies have already recognized 
and analyzed the phenomenon of maps for conservation (Harris and Hazen 2006, Kidd 2019). Also, the flourishing literature of science and technology studies covers the transformative power of new ICT-based devices (sensors, automatic measures, drones) in our understanding of environmental issues (Gabrys 2016). However, both scientific inquiries are mostly focused on nature preservation areas located outside cities or in general environmental problems, ignoring their location. Very few studies analyzed the urban environmental condition through counter-mapping (Connors et al. 2012, Syngellakis et al. 2018). Yet, even those studies, to a lesser extent, explore the perspective of counter-mapping as strategies of urban environmental movements in order to support their critical standpoint towards urban politics. The aim of this paper is to fulfil this gap by investigating the main strategies of using such tools and their effects for both particular social actors and general urban environmental policy, taking smog alerts and urban greenery movements as an example. By tracking their usage of social mapping in reaction to official environmental data, we want to explore the possibilities and limitations of such tools for the purposes of environmental urban social movements.

\section{METHODOLOGY}

In this study we applied qualitative data analysis with different research strategies for the cases of urban greenery and air quality movements. Our analytical unit was a mapping strategy of the selected urban environmental movement, on the basis of the review of the broader informational context. For smog alarms, the main source was a database content package of 18,575 Facebook posts published by 89 smog alerts between 2014 and 2018 extracted by the Netvizz application (Rieder 2013). Even though Facebook withdrew this application in September 2019, we found this content appropriate for analysis because of its nationwide coverage (Frankowski 2020). In the case of urban greenery movements, we used a database of 215 Google alerts from the years 2014-2018 containing around 700 Polish-language internet news items tagged as 'urban greenery' (Polish: 'zieleń w mieście'). As chosen by the internet search engine from all available internet sources, news in this database could be treated as randomly selected.

On the basis of the imported database analysis, we carefully tracked the activity of both smog alerts and urban greenery movements for various examples of counter-mapping, understood as mentioned above, as grassroots counter-mapping aimed at conquering dominant urban environmental politics. Our inventory is obviously biased in favor of the activities widely promoted in traditional and social media. However, taking into consideration the specific (geo)social features of counter-mapping, promoting citizen-driven data collection should be a necessary characteristic of the activities which we are looking for. The second limitation of our analysis was tracking just two types out of many urban environmental movements (concerning sustainable transportation, animal and wildlife issues, water, etc.).

Still, we think that an inventory of mapping the experiences of air quality and urban greenery issues as a form of 'process tracing' (Bennett and Checkel 2014) is a 
convenient research strategy. According to the typology of Polish urban movements (Nowak and Pluciński 2017), we situated smog alerts and urban greenery initiatives at the intersection of middle-income class movements and local actions. Thus, their experiences should be representative of other urban movements of similar origin. Moreover, air pollution and the state of urban greenery have common characteristics in being almost 'invisible' to the 'layperson' if not detected by technical means (metrics, sensors) and scientific deliverables (Irwin and Michael 2003; Sandberg et al 2015; Gabrys 2016). Thus, the state and the strength of social trust in the knowledge system 'delivering' those threats directly influences its effectiveness. On the other hand, the highly scientific realm of environmental debates, including urban air quality and urban greenery, can have a 'backlash effect' in decreasing public engagement because it marginalizes other ways of understanding environmental problems, e.g. through local consequences and alternative solutions for societal and economic development (Lidskog and Sundqvist 2018). Thus, issues of urban greenery and air pollution are indicated in the analysis as particularly driven by the question of public engagement in data collection and 'strengthening the voice' of science by social actors, e.g. social movements and protest groups, which are both crucial and challenge the achievements in recent environmental governance.

The analysis will present several strategies of using counter-maps by two chosen groups of urban environmental movements in reaction to official environmental data. For smog alerts they proved to be a bottom-up reuse of public data and open sensing maps, while for urban greenery movements they were mental maps of valuable greenery and map-based inventories of threatened greenery. The results will look for characteristics in the two analyzed types of urban movements and then describe if and how they are similar in relation to analyzed factors of enhancing public debate on environmental issues and challenging official representations of environmental problems. We hope that our inventory and the typology of strategies we have created from them can supplement and further develop the number of existing in-depth studies of particular mapping initiatives. Through the inventory associated with chosen examples, we tried to grasp the evolution of those participatory mapping efforts and discuss their role and further potential in urban environmental movements in Poland.

\section{COUNTER-MAPPING PRACTICES OF SMOG ALERTS AND URBAN GREENERY MOVEMENTS}

The last decade brought a revival of grassroots movements to Polish environmental governance (Szulecka and Szulecki 2017). Urban conditions proved to be particularly prone to environmental problems as they brought issues of health, well-being, and a renascent community spirit into public debate on power relations and economic priorities. Characteristically, appearance of both analyzed examples of such urban environmental revival, smog alerts, and urban greenery movements, directly depended on 'spatiality' of environmental problems. Discussion of public air quality would not have been possible without the introduction of a nationwide air pollution monitoring scheme (2001) as an implementation of the EU 96/62 Directive (Bogucka et al. 2004). 
Similarly, urban greenery movements resulted to some extent from the introduction of participatory mechanisms to spatial procedures (e.g. Environmental Impact Assessment, EIA in 2008, public consultations) and development of geoportals enabling online map browsing (e.g. geoportal.gov in 2008). The emergence of both examples demonstrated that an issue of what is 'known' and 'unknown' in terms of environmental problems would determine their actions.

In terms of air pollution, starting from Cracow in 2012, more than 100 grassroots movements grew up in most Polish large and middle-sized towns. Their first and foremost aim was to publicize the existence of an air pollution problem and its main sources, low quality solid fuel burning and intensive car traffic, in order to upgrade this theme to the policy mainstream (Frankowski 2020). From its very beginning, this public discussion circled around two scientific- and technology-based controversies on delimitation of alarming pollution levels and on appropriate density of measuring points around the country. Similarly, rising awareness of benefits to the ecosystem from urban greenery led to heated local opposition against tree logging ${ }^{1}$ which gained intensity due to the rapid development of infrastructure and investment pressure after the political transformation and then after Poland's accession to the EU (Putkowska-Smoter 2020). The often informal and local character of those actions makes it impossible to accurately assess the scale of this phenomenon, however, general scientific observations on urban environmental protection would indicate a steady trend in the occurrence of conflicts over urban nature in Polish cities (Mergler, Wudarski, Pobłocki 2013; Pawłowska 2012; Siemieński and Bida-Wawryniuk 2016). Among diagnosed threats to urban greenery in Poland were its poor condition due to past neglect, insufficient funds, or strong investment pressure (NIK 2015), and management deficiencies, especially insufficiency in data collection about urban greenery (Kronenberg 2012; strategic planning document of Cracow 2015 and Warsaw 2017 ). Moreover, national reports on climate change highlight the vulnerability of Polish cities and their ecosystems to negative climate effects such as urban heat islands or extreme weather events (Polish National Strategy for Adaptation to Climate 2020; The 2030 National Environmental Policy) which requires more dynamic, detailed, and real-time monitoring of urban greenery. However, in 2014 only two the biggest cities - Cracow and Warsaw - had already undergone comprehensive tree inventories while several other cities had done a partial inventory of particular green spaces (e.g. in regenerated areas). Despite several efforts of NGOs to support public entities in collecting data through PP GIS (see Sendzimir Foundation 2014 and Jankowski et al. 2018), available urban greenery maps were still missing in many cities over the period under analysis. Lack of public data significantly limited the possibilities for social actors to monitor and protect the state of urban greenery. Therefore, next to 'conservative' arguments against tree logging, struggles around urban greenery were often driven by the postulate of wider public participation in environmental decision-making by providing data

\footnotetext{
${ }^{1}$ For instance, in the capital city of Warsaw alone, at least 18 such protests occurred in 2010-2018 (Putkowska-Smoter 2020). Also, considering its importance, fighting for urban nature was listed among one of main postulates of Urban Theses (2015) formed by the Congress of Polish Urban Movements which serves as a source of recognized issues raised during local environmental debates all over the country.
} 
on urban trees and planned felling.

Both the urban movements analyzed transformed over time from individual and loosely connected local initiatives, through formalized local associations (e.g. Krakow Smog Alert - Krakowski Alarm Smogowy or Ochocianie Association - Stowarzyszenie Ochocianie in Warsaw) to collective and cooperative bodies (Polish Smog Alarm and branch of National Congress of Urban Movements). They also diversified their approaches, which included both involvement in public consultations and participatory actions coordinated by local and national authorities, as well as practices outside collaboration such as petitions, protests, and informational campaigns. Mapping activities proved to be particularly important initiatives in the maturing of those movements, addressing recognized challenges, mobilizing people around environmental problems and visualizing alternative solutions. Below we present an inventory of such activities grouped into four illustrative strategies of bottom-up citizen participatory mapping concerning air pollution and urban greenery which - we think - support this thesis.

\section{BOTTOM-UP REUSE OF PUBLIC DATA}

Even though specialized smog alerts took over the central position in public discussion, a fight for clean air remained the main postulate for traditional Polish urban movements. One of the most powerful antismog social movement initiatives was the 'Warsaw Map of Dirty Stoves' made by Miasto Jest Nasze (The City is Ours) - a Warsaw-based urban movement, also the initiator of Warsaw Smog Alert. The organization mapped the location of 1,934 municipal apartments heated by low-quality solid fuel stoves [GW: Czarna Walentynka 2018]. Data were collected through public information requests directed to the municipal housing management agency in 2017. Every selected location provided data about the address and number of municipal apartments using low-quality coal stoves for heating. Moreover, the authors placed on this map all nearby kindergarten locations in order to strengthen the issue of the consequences of the problem created by this source of air pollution.

The map was established to accelerate coal stove replacement by the City Office. Using public data as 'weapon' as well as the basis of powerful and professional visualization resonated in national and local media. On the same day, a local government representative promised to replace all municipal stoves by the end of 2019 (Portal Samorządowy 2018). In the meantime, activists monitored the progress of intervention (Kopeć, Chełmiński, Korzeniowska 2019) and repeated public information requests, then pointing out insufficient momentum and low data quality in some districts (Chełmiński 28.10.2019). Interestingly, after the election in 2018 one of the map creators became a director for sustainable development, including for green areas and air pollution management, responsible also for removing stoves from municipal buildings. During winter 2019/20, the president of Warsaw, under pressure from urban movements, decided to phase out coal heating not only in municipal offices, but also to prohibit individual solid fuel stoves until the end of 2023.

The example of the 'Warsaw Map of Dirty Stoves' shows that urban movements 
assumed that City Office should be a 'model' institution which ought to set standards and solve the smog problem, beginning within their own housing resources. They used public information in this neglected urban policy area and then prepared a precise and visually attractive map, which is also evidence of their technological capacity. However, identifying individual buildings on the map with their precise addresses may stigmatize less affluent citizens. Even though there are some smog alert initiatives which combine the map with addresses and even the emission evidence such as photography, the other alerts recognized that such practices may antagonize the local community and it is their duty to protect vulnerable people (Skawiński Smog Alert, Facebook post, 4.10.2017).

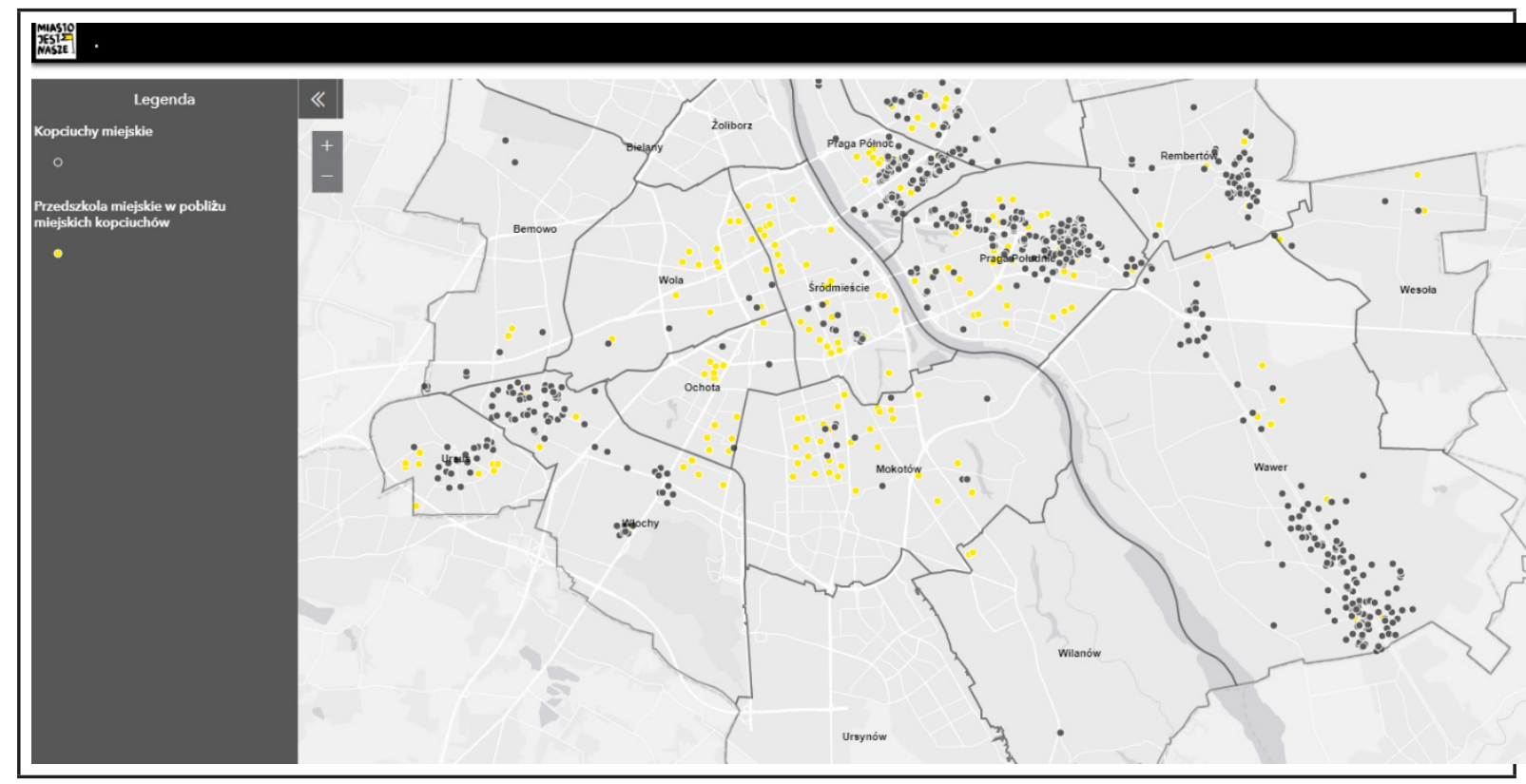

Authors: Environmental Committee of Miasto jest Nasze Movement (Komisja ds. ochrony środowiska Ruchu Miasto Jest Nasze). Source of the map: https://miastojestnasze.org/smog/.

\section{CITIZEN SENSING}

While the 'Warsaw Map of Dirty Stoves' nuanced the reasons for air pollution, citizen sensing pays attention to the harmful consequences of smog. Official air pollution maps were based on public system monitoring. Because of a relatively small public air measurement station network, smog alerts often consisted of insufficient numbers and locations of such devices. To produce valid environmental information, they encouraged local authorities to buy such devices, comparing with a neighboring city as a benchmark (e.g. Sulechów to Zielona Góra, Racibórz to Wodzisław Śląski, Gniezno to Poznań). In case of local authority resistance to investment in air measurement stations, smog alerts practiced borrowing dust meters, mobilizing money for information boards and sensors within participatory budgets, harvesting money through private company CSR, and encouraging people in locating their own air measurement 
stations.

Insufficient sensor density ought to mobilize citizens to acquire better knowledge of health issues and being 'energy citizens' (Devine-Wright 2007). This approach also resonates with the different, broader expectations regarding urban inhabitants - as prosumers, microdevelopers, and co-producers, especially in the areas beyond the official regulations (Frąckowiak 2016). However, as far as borrowing dust meters and buying smog stations through participatory budgets were popular in the early smog alert activity, nowadays the cost of air pollution sensors has fallen significantly and people decided to establish private air measurement stations. Such devices enabled production of real-time data and sent to the commercial and non-commercial general air pollution map providers such as AirMonitor or OpenSenseMap. OpenSensing Movements can be read as an 'energy citizenship' issue: taking personal responsibility for the selected land area and delivering evidence about its conditions. However, it can be read also as a threat of public duty privatization or outsourcing. The rapid development of this movement may affect the measurement quality negatively: some information can be biased, dispersed, incomparable, or disclosed. Moreover, commercial companies try to use that citizen engagement, sometimes offering the 'sensor ambassador' position. In those cases, such grassroots ideas may be used intentionally and monetized by a dynamic and increasing market of 'smart-city' technologies and providers.

\section{RESTORE TREE ON THE MAP}

One of the challenges recognized by urban greenery movements was a specific 'invisibility' of urban trees in public decision-making. In many conflicting cases, urban trees entered a public debate only when they were going to be cut. On such occasions, trees were presented mainly as obstacles colliding with planned investments, and sick, damaged, or life-threatening. This was the reason why large parts of inventoried counter-mapping activities were aimed at 'restoring' the value of urban trees on the maps. Thus, we recognized several examples similar to traditional 'parish maps' (Wood 2005) in which tree mapping activities served the role of local guided tours among particularly interesting or important elements of urban nature. Those actions were often recalling individual memories and sentiment in order to (re)create 'green' mental maps of close surroundings.

For instance, green areas and particular trees appeared on several 'sentimental maps' collected under grassroots urban projects, e.g. in Poznań (in 2018 by Malta Festival Poznań) or in Lublin (in 2018 by Lubelska Grupa Badawcza). Trees are important witnesses to local history which now are subject to rapid development. As stated in this quotation from one of the stamps on sentimental maps prepared in Lublin: 'Oak, which grows between the lanes of Monte Cassino Heroes Street, is the only remnant of the farm that once existed here in the past. This tree was chosen by the jury and internet users as the Treasury of Space Culture. The oak is also proof that you can plan the city development in such a way to save nature'2. Along with this trend, in several cities lo-

\footnotetext{
${ }^{2}$ https://drive.google.com/file/d/1Z44E3Ds6rOdAeuvfUYS6vx_OOS 11MTe/view
} 
cal activists developed various maps of environmentally valuable trees. In Warsaw in 2015, the artistic collective RośnijWAW organized several walking tours with citizens of Warsaw to identify interesting green areas and then collected all the points on the printed map. The walks were very popular, they were held in cooperation with other urban environmental activists and they were associated with a contest and educational campaign about urban gardening (called 'Warszawa w kwiatach i zieleni'). In Cracow, inspired by a local environmental NGO, citizens mapped 'Dokąd tupta jeż' (English: where the hedgehogs trot) places where meeting hedgehogs is possible. As a result, 200 places were reported. The idea of this sympathetic action was to pay attention to the need of protecting urban flora and fauna, thus it was followed by recreating more favorable conditions in reported places (planting trees, shrubs, and grassland) for hedgehogs and other urban animals. Similarly, two other environmental NGOs - Fundacja Ekorozwoju and Klub Gaja created maps of valuable trees reported by citizens under their community educational actions - Święto Drzewa and Aleje dla Natury. Several tourist maps with interesting specimens of trees and descriptions of their history were created as a result.

All those activities gained significant social recognition, through traditional and social media, as easy to explore, spontaneously expand, and possible to replicate in other locations. They also often referred to urban nature as highly valuable (from many angles) but underestimated the often invisible elements of urban spaces. In this context, counter-mapping served a role of a symbolic act aimed at restoring ('adding') nature within the urban environment and in highlighting its potential to bring people together (as in community-driven mappings via social media and walking tours around city).

Screenshot of map-based mobile applications: ‘Trees with the atmosphere’ (PL ‘Drzewa z klimatem’)

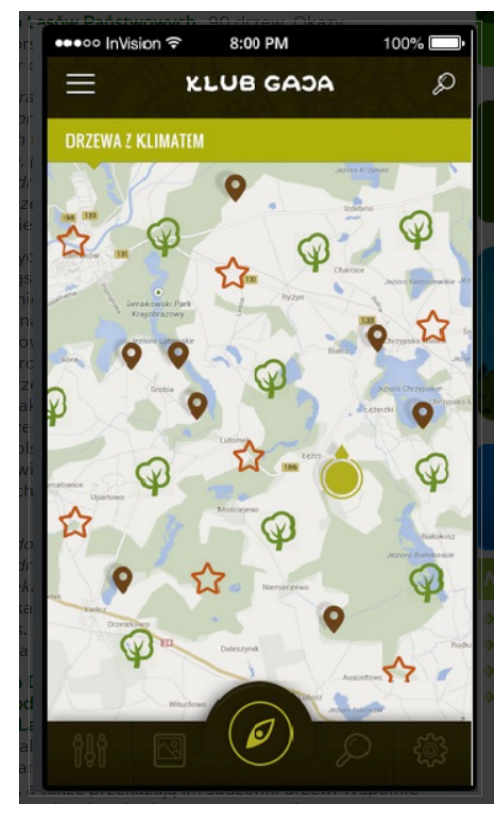

Authors: Klub Gaja. Source of the map: http://swietodrzewa.pl/?page_id=5907

Redrawing boundaries of social control 
The second group of the existing usage of social mapping were inventories of threatened greenery and bottom-up notifications about illegal felling or inappropriate care of newly planted trees. This trend may have resulted from popular expectation of evidence-based environmental governance which led to critical evaluation of available sources and databases about urban nature. As already stated above, Polish local administrative units are often criticized for having partial, outdated, and incomparable datasets of urban greenery which limit their capacities to strategically govern such resources. This problem raises particular attention because of increasing recognition of environmental challenges, such as the above-mentioned air pollution or climate changes, showing up in the form of heavy rainfall and urban heat islands.

Thus, social mapping proved to be useful in order to supplement environmental debate with 'green numbers' and updates about the state of urban greenery. In several locations (e.g. Poznań, Warsaw, Łódź), urban activists started bottom-up tree inventories aimed in fulfilling diagnosed gaps in local environmental data. Providing additional data was often followed by more advanced social and educational goals. For instance, a description of an informal group from Łódź called 'social tree caretakers' (Polish: społeczni opiekunowie drzew) involved in such bottom-up voluntary tree inventory recording also contained goals of 'drawing attention to the problem of lack of care for trees' and 'conducting educational activities about the importance of trees' ${ }^{3}$. In Opole and Wrocław, requests and expectations on adding or restoring urban greenery were collected through social media and then visualized as maps of 'green needs'. Once again, such collections were driven by aims beyond adding information. For instance, in Wrocław several individual initiatives involved in urban greenery mapping (e.g. Fundacja EkoRozwoju, AkcjaMiasto, Zieleń Wrocławska and MiastoDrzew) cooperated with each other in lobbying for urban greenery development at the city level. Finally, there were also some attempts to map inappropriate states of urban greenery. For instance, in Ursynów (district of Warsaw), local citizens created a map of newly planted trees which suffered from drying out. Inspired by this mapping, local and social media debated how to recognize trees in poor condition, and more widely the problem of urban drought as a result of climate change.

Despite the fact that all the above examples just relied on lay citizen data, they proved to be useful and inspiring for local governments. For instance, in the analyzed period several cities prepared professional GIS-based tree inventories and urban greenery maps. Moreover, the cities of Warsaw, Cracow, Łódź, Poznań, and Wrocław began sharing data on urban greenery on interactive maps. However, local low-tech solutions proved to be particularly useful once again for several months in 2017. Then, the law named after the incumbent Minister of the Environment - Jan Szyszko as 'lex Szyszko' - allowed the cutting of trees on private land virtually without legal arrangements or environmental permits. The massive effects of this unexpected relaxation of regulations showed that local governments have limited ability to monitor and protect trees on private land. In response, we reported at least 20 cities which benefited from 'lex Szyszko felling’ maps hosted by local media websites or Google Maps, which

${ }^{3}$ https://spoleczniezaangazowani.pl/projekty/spoleczni-opiekunowie-drzew/ 
monitored the state of trees in urban private areas and reported on ongoing felling in order to help local governors in controlling them. In most of the cases, those maps were the only public tools covering information and pictures of trees that disappeared.

Screenshot of map-based website on tree logging (example from Cracow)

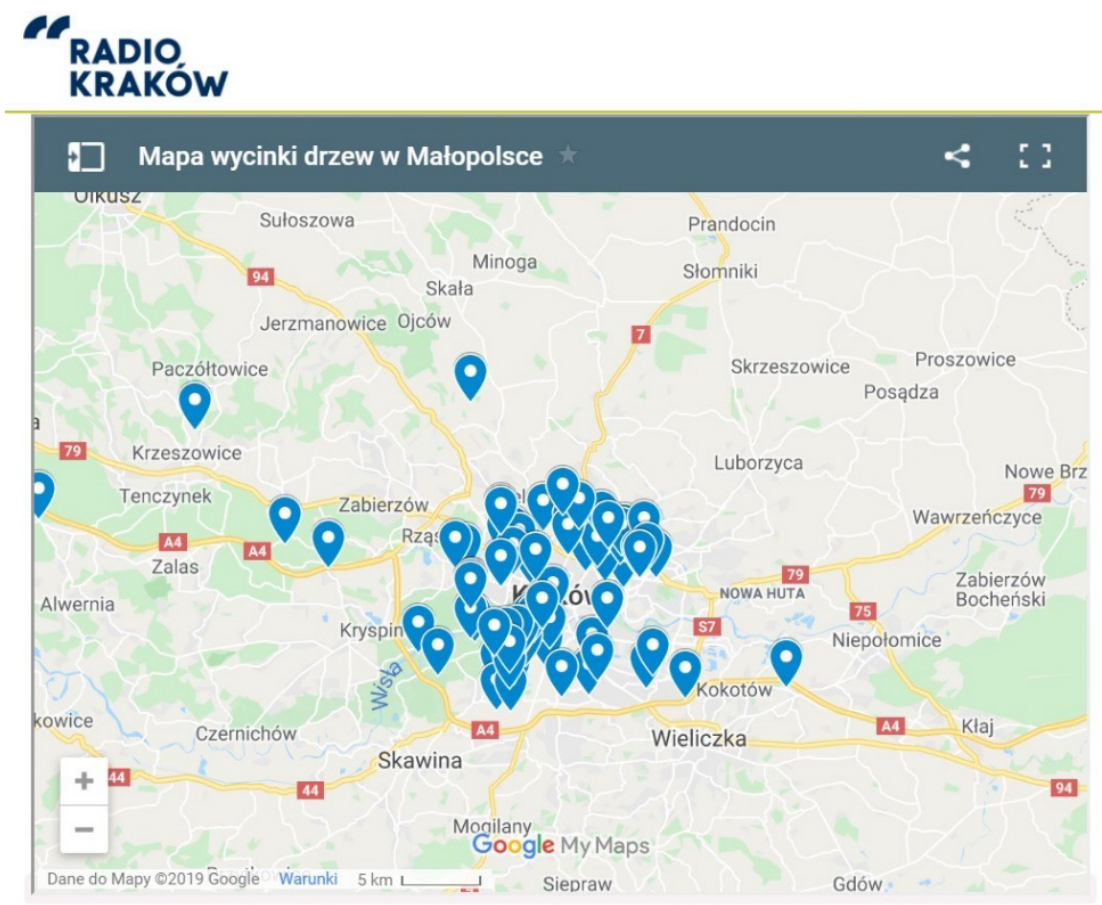

Authors: Internet users coordinated by local Radio Kraków. Source of the map: https://www. radiokrakow.pl/wiadomosci/aktualnosci/gdzie-zniknely-nasze-drzewa-tworzymy-mape-wycinek-w-malopolsce-interaktywna-mapa/

This group of examples illustrates that simple, citizen-based maps of urban greenery still have potential in supporting environmental debate with up-to-date local information and unique social context. Above all, the maps serve as a message to local governments about the expected level of availability (being transparent, public, interactive, online) and accuracy (covering particular trees and their dynamic status) of environmental data. In a metaphorical sense, using the recognized spatial procedure of mapping in the form of a monitoring tool can 'add' social control as an additional 'layer' to rather managerial, professionalized, and top-down environmental governance.

\section{DISCUSSION}

In both examples we could observe how various counter-mapping activities were mainly planned to challenge official representations of environmental problems and to reconfigure relations between actors in the environmental debate. By using mapping tools, smog alerts undermined official top-to-bottom environmental policy by promoting citizenship data requests and citizen sensing on the basis of their own data, collected in real time. They also were pressing local governments to choose a commit- 
ted and comprehensive approach to air quality problems. Similarly, the maps prepared by urban greenery movements pointed to several inadequacies and deficiencies in official urban data on trees. Again, the citizens and their knowledge of the local context were promoted as a valid source of complementary information in the multi-layered and complex urban greenery dynamics. The following table outlines those results.

Table 1. Main functions of counter-mapping tools in analyzed examples

\begin{tabular}{|c|c|c|c|c|}
\hline Strategy & $\begin{array}{l}\text { Examples } \\
\text { of count- } \\
\text { er-map- } \\
\text { ping }\end{array}$ & $\begin{array}{c}\text { Public } \\
\text { data } \\
\text { sources } \\
\text { in refer- } \\
\text { ence }\end{array}$ & $\begin{array}{l}\text { Alternative } \\
\text { data sources }\end{array}$ & $\begin{array}{c}\text { Functions of contra-mapping tool in reference to } \\
\text { official data }\end{array}$ \\
\hline \multirow{2}{*}{$\begin{array}{l}\text { Challeng- } \\
\text { ing offi- } \\
\text { cial repre- } \\
\text { sentations } \\
\text { of envi- } \\
\text { ronmental } \\
\text { problems }\end{array}$} & $\begin{array}{l}\text { Bottom-up } \\
\text { reuse of } \\
\text { public } \\
\text { data }\end{array}$ & $\begin{array}{l}\text { Municipal } \\
\text { housing } \\
\text { data } \\
\text { (available } \\
\text { on re- } \\
\text { quest) }\end{array}$ & $\begin{array}{l}\text { Reconfigured } \\
\text { and spatial- } \\
\text { ized munic- } \\
\text { ipal housing } \\
\text { data com- } \\
\text { bined with } \\
\text { other layers } \\
\text { (such as kin- } \\
\text { dergartens) }\end{array}$ & $\begin{array}{l}\text { Visualization of the condition of local administration } \\
\text { resources to get attention and effectively mobilize peo- } \\
\text { ple around the air pollution problem from municipal } \\
\text { housing. }\end{array}$ \\
\hline & $\begin{array}{l}\text { Restore } \\
\text { tree on the } \\
\text { map }\end{array}$ & $\begin{array}{l}\text { Public } \\
\text { urban } \\
\text { greenery } \\
\text { and spa- } \\
\text { tial data }\end{array}$ & $\begin{array}{l}\text { Mental im- } \\
\text { ages (senti- } \\
\text { ments, expe- } \\
\text { riences) }\end{array}$ & $\begin{array}{l}\text { Promoting of and giving importance to urban nature fea- } \\
\text { tures 'invisible' from official data point of view in order } \\
\text { to mobilize people around urban greenery protection. }\end{array}$ \\
\hline \multirow{2}{*}{$\begin{array}{l}\text { Recon- } \\
\text { figuring } \\
\text { relations } \\
\text { between } \\
\text { actors of } \\
\text { environ- } \\
\text { mental } \\
\text { debate }\end{array}$} & $\begin{array}{l}\text { Citizen } \\
\text { sensing }\end{array}$ & $\begin{array}{l}\text { National } \\
\text { air pollu- } \\
\text { tion mea- } \\
\text { suring } \\
\text { system }\end{array}$ & $\begin{array}{l}\text { Sensor mea- } \\
\text { surement }\end{array}$ & $\begin{array}{l}\text { Fulfilling the public sector shortcomings through en- } \\
\text { larging official air pollution measuring system by private } \\
\text { resources. }\end{array}$ \\
\hline & $\begin{array}{l}\text { Redrawing } \\
\text { bound- } \\
\text { aries of } \\
\text { social } \\
\text { control }\end{array}$ & $\begin{array}{l}\text { No data } \\
\text { or limit- } \\
\text { ed data } \\
\text { available }\end{array}$ & $\begin{array}{l}\text { Local knowl- } \\
\text { edge (ob- } \\
\text { servations, } \\
\text { pictures) }\end{array}$ & $\begin{array}{l}\text { Monitoring and filling up local administration efforts in } \\
\text { taking care about urban nature by including local knowl- } \\
\text { edge and everyday experiences of citizens. }\end{array}$ \\
\hline
\end{tabular}

Source: own elaboration

Despite all the above-mentioned similarities between smog alerts and urban greenery movements, there are also some separating characteristics in using citizen-driven mapping activities in reference to official data. We observed that smog alert activities have a more direct and questioning character towards official data than urban greenery ones, unlike urban greenery mapping activities which were more into promoting alternative layers of geospatial information concentrated on social relations and local need. Using the Elwood et al. (2012) division, we could say that smog alert mapping was oriented towards geoinformation, while urban greenery mapping is towards geosocial and geovisualizing. This may be due to differences in the preconditions and nature of the environmental problems raised. First of all, availability of official data on air quality enabled critical analysis by social actors and open discussion about alternatives. Insufficiency of urban greenery data differently directed mapping activities into local needs-related and ad hoc data collections. The perceived 'hazardousness' of air 
pollution led to towards more confrontational measures in this area. The shared positive image of urban trees and a 'conservationist' approach makes the debate around this issue tend toward sharing experiences and 'make them visible' approaches, closer to traditional 'parish maps'. Those findings might be a useful suggestion for further studies and practitioners to take into account the advancement of public data as well as the nature of reality being mapped while crafting an appropriate mapping tool.

However, as already pointed out in the relevant literature, growing popularity and availability of mapping tools rises ethical questions. We found this aspect of counter-mapping rather underrated in tracked activities, although it is particularly relevant in the case of so called 'shaming and blaming' types of mapping initiatives. They should address their postulates rather to the people in power than to a neighborhood which sometimes lacks complex knowledge about energy usage or urban gardening conditions and possibilities. Neglecting such limitations while preparing maps with addresses could stigmatize less affluent people and, in consequence, weaken social ties in local communities. Secondly, the high-tech, still costly, and health-related character of air pollution measurements encourages involvement of private entities which can have commercial interests, e.g. in sale or promotion of their own measurement systems. If those particular interests try to (in reality or by the interpretation of other actors) cover social and public areas, urban movement activities associated with such entities may lose their legitimacy to act on behalf of local citizens. This threat can be relevant to urban greenery movements as well as if they decided to use commercial greenery inventory systems.

Our results are also relevant to the introductory discussion about counter-mapping meeting the needs of environmental urban social movements. Undoubtedly in both cases, choosing mapping tools was a strategic decision. They proved to be simple, dynamic, easy to promote, involving, and rich in symbolic meanings. In such a way map-based tools confirm that they can fit several characteristic features of urban environmental movements. For instance, dynamic and collectively filled-up maps mirror informal and 'network-based' structures of environmental movements (Castells 1996). As open for almost all to contribute, they can both arouse interest and encourage the commitment of citizens. Thus, we agree with Rocio et al. (2013) that maps can be particularly effective as a first step in undertaking grassroots and participatory community action.

However, we see some limitations in this mobilization and educational potential. Almost all the above-mentioned maps, except the Warsaw Map of Dirty Stoves, were limited in moderation or data checking and were enriched by direct proposals for further 'real world' actions. Lack of control over data flow can reduce the reliability of the data collected and thus, usefulness as an alternative source of urban knowledge. Also, cutting 'real world' actions out of the map can contribute to digital exclusion and lead to limiting the involvement of residents to negatively evaluated 'slacktivism' when online actions (in the form of clicks/likes/shares/comments, etc.) are not translated into any 'real' environmental actions or attitudes (Christensen 2012).

On the other hand, the richness of maps in metaphors and symbolic meanings (e.g. adding to the maps what is 'invisible', overcoming official maps/data, providing new 
knowledge out of the 'collective' mind etc.) can only strengthen the value-creation strategies of environmental movements. Using that potential, urban actors can influence local authorities more effectively by referring to values such as public health, urban solidarity, or environmental injustice. Obviously, the technical quality of data obtained by social mapping is insufficient to be directly incorporated to official datasets. However, there are several examples that maps, as visualizations and dynamic illustrations of environmental problems, encouraged local authorities to actively look for new or more accurate solutions, at least at a declarative level.

Going beyond the fact that counter-maps can be easily used and misused by urban environmental movements, we can also conclude that such tools in the broader sense bring new technologies as solutions to urban environmental problems. In both the analyzed cases the core idea of conquering the dominant geospatial system (mainly through collecting valuable alternative datasets) were strongly supported by other features of citizen-driven geospatial mapping - social tightening, educational goals, and collective production of 'visualizations' aimed at illustrating the scale and dynamics of particular environmental problems. Moreover, instead of resolving environmental problems, adding more data resulted in complication of the overall picture and multiplication of the views and interests towards those particular problems. This supports general findings from recent literature that usage of GIS-based tools could significantly differ depending on actors' objectives (Sieber 2006). It may also suggest that various forms of maps (official, participatory GIS, counter-mapping) are not mutually exclusive and in contrast to the idea of overcoming spatial conflicts by more inclusive and participatory mapmaking, various forms of counter maps can still function in parallel at different stages of the environmental debates.

Finally, even if counter-mapping was relatively effective in challenging power relations over environmental knowledge and decision-making, there is still little evidence of its success in overcoming or eventually changing those relations. Thus, we agree with Grabkowska et al. (2015) that similar to many other technologically advanced ICT solutions, maps should be treated mainly as a tool rather than as a solution to urban environmental problems and struggles over their solutions. More generally, we would agree with warnings of McCormick (2007) that critical engagement of social movements with official research and data can be benefiting for those actors to gain the necessary credibility but it would not be enough to impact politics, which is influenced also (or mainly) by factors other than research evidence, such as power relations and economic priorities. On the other hand, by using the 'power of maps' as alternative and challenging ways of collecting and exploring official data, urban environmental movements introduce themselves to the next level of critical urban politics which is focused on data production. We treat it as a sign that despite ongoing debates and hopes related to political concepts such as smart city and urban sustainable development, possible tools of contestation are probably an inherent part of every single (current and forthcoming) urban managerial practice. 


\section{CONCLUSIONS}

The aim of this paper was to explore the evolution of counter-mapping efforts of environmental urban social movements and discuss the role and further potential of such practices for critical urban politics. We argue that urban environmental movements used the social potential and visualization of geospatial data to challenge official representations of environmental problems and thereby change the power relations between actors involved in urban governance. In these two separated strategies, maps as a contestation tool - play different, specific functions: not only filling public sector failures and knowledge deficiencies, but also promoting, explaining, and mobilizing society around the visible and invisible common good. Counter-mapping remains a boosting and attracting device, but it also requires complementary activities to be both an effective and engaging tool. In times of a growing 'sharing economy', voluntary data activism, opening public datasets, and increasing the technological capacity of social movements, the role of maps will probably grow, and urban environmental movements will be more engaged and in a better position to reclaim the 'right to the city' through repoliticizing urban environmental data.

FUNDING: This work was financially supported by the Polish National Science Centre [PRELUDIUM grant number 2018/31/N/HS6/03357].

CONFLICT OF INTEREST: The authors declare no conflict of interest.

ACKNOWLEDGEMENTS: The authors would like to thank the Polish National Science Centre for funding the research, and the reviewers for their thoughtful comments.

\section{REFERENCES}

Bąkowska, Edyta, Tomasz Kaczmarek, Zbigniew Zwoliński, Łukasz Mikuła, Michał Czepkiewicz, Piotr Jankowski, and Cezary Brudka. 2016. 'Geo-questionnaire in urban planning: preliminary results of the experimental application in Poland'. Rozwój Regionalny i Polityka Regionalna 35: 37-54.

Béal, Vincent. 2012. 'Urban Governance, Sustainability and Environmental Movements: Post-Democracy in French and British Cities'. European Urban and Regional Studies 19(4):404-19.

Bennett, Andrew, and Jeffrey T. Checkel, eds. 2015. Process Tracing: From Metaphor to Analytic Tool. Cambridge ; New York: Cambridge University Press.

Bergier, Tomasz, and Kronenberg, Jakub. 2012. 'Polski poradnik TEEB dla miast. Zrównoważony Rozwój - Zastosowania nr 3'. Kraków: Fundacja Sendzimira

Bogucka, Magdalena, eds. 2004. Zanieczyszczenie powietrza w Polsce w latach 20032004. Warszawa: Biblioteka Monitoringu Środowiska.

Bruno, Isabelle, Emmanuel Didier, and Tommaso Vitale. 2014. 'Statactivism: Forms of 
Action between Disclosure and Affirmation'. Partecipazione e Conflitto 7(2):198220.

Castells, Manuel. 1983. The City and the Grassroots: A Cross-Cultural Theory of Urban Social Movements. Berkeley: University of California Press.

Ceccaroni, Luigi, and Jaume Piera, eds. 2017. Analyzing the Role of Citizen Science in Modern Research: IGI Global.

Chełmiński, Jakub. 2018. 'Akcja Miasto Jest Nasze: Smogowa Mapa Warszawy i Czarne Serce Dla Hanny Gronkiewicz-Waltz’. Gazeta Wyborcza Warszawa, February 14.

Chełmiński, Jakub. 2019. 'Kopciuchy Zatrują Warszawę. W Niektórych Dzielnicach Pieców Przybyło. Mamy Najnowsze Dane’. Gazeta Wyborcza Warszawa, October 28.

Christensen, Henrik Serup. 2012. 'Simply Slacktivism? Internet Participation in Finland'. JeDEM - EJournal of EDemocracy and Open Government 4(1):1-23.

Connors, John Patrick, Shufei Lei, and Maggi Kelly. 2012. 'Citizen Science in the Age of Neogeography: Utilizing Volunteered Geographic Information for Environmental Monitoring'. Annals of the Association of American Geographers 102(6):126789.

Cowart, Alicia, and Susan Powell. 2019. 'Guerrilla Cartography: Promoting Diverse Perspectives and the Expansion of the Cartographic Arts'. Cartographic Perspectives 92, 58-64.

Crampton, Jeremy. 2008. 'Will Peasants Map? Hyperlinks, Map Mashups, and the Future of Information'. The Hyperlinked Society: Questioning Connections in the Digital Age 206-26.

Crampton, Jeremy W. 2001. 'Maps as Social Constructions: Power, Communication and Visualization'. Progress in Human Geography 25(2):235-52.

Dalton C., and Mason-Deese L. 2012. 'Counter (Mapping) Actions: Mapping as Militant Research'. ACME ACME 11(3):439-66.

Dalton, Craig M., and Tim Stallmann. 2018. 'Counter-Mapping Data Science: Counter-Mapping’. The Canadian Geographer / Le Géographe Canadien 62(1):93-101.

Devine-Wright, Patrick. 2007. 'Energy Citizenship: Psychological Aspects of Evolution in Sustainable Energy Technologies'. Framing the Present, Shaping the Future: Contemporary Governance of Sustainable Technologies 63-86.

Domaradzka, Anna. 2018. 'Urban Social Movements and the Right to the City: An Introduction to the Special Issue on Urban Mobilization'. VOLUNTAS: International Journal of Voluntary and Nonprofit Organizations 29(4):607-20.

Dovey, Kim, and Mirjana Ristic. 2017. 'Mapping Urban Assemblages: The Production of Spatial Knowledge'. Journal of Urbanism: International Research on Placemaking and Urban Sustainability 10(1):15-28.

Elwood, Sarah. 2006. 'Critical Issues in Participatory GIS: Deconstructions, Reconstructions, and New Research Directions'. Transactions in GIS 10(5):693-708.

Elwood, Sarah, Michael F. Goodchild, and Daniel Z. Sui. 2012. 'Researching Volunteered Geographic Information: Spatial Data, Geographic Research, and New Social Practice'. Annals of the Association of American Geographers 102(3):571-90.

Frąckowiak, Maciej. 2016. 'Miasto z Otwartym Kodem. W Poszukiwaniu Sposobów Na 
Uspołecznienie Przestrzeni Publicznych’. Przegląd Socjologiczny 65(1): 49-63.

Frankowski, Jan. 2020. 'Attention: Smog Alert! Citizen Engagement for Clean Air and Its Consequences for Fuel Poverty in Poland.' Energy and Buildings 207:109525.

Gabrys, Jennifer. 2016. Program Earth: Environmental Sensing Technology and the Making of a Computational Planet. Minneapolis: University of Minnesota Press.

Grabkowska, Maja, Łukasz Pancewicz, and Iwona Sagan. 2015. 'The Impact of Information and Communication Technology on the Rise of Urban Social Movements in Poland'. Pp. 93-113 in Emerging Issues, Challenges, and Opportunities in Urban E-Planning. Hershey.

Habermas, Jürgen. 1985. Reason and the Rationalization of Society. Nachdr. Boston: Beacon.

Habermas, Jürgen, and Jeremy J. Shapiro. 1971. Toward a Rational Society: Student Protest, Science, and Politics. First paperback ed . [Nachdr.]. Boston: Beacon.

Harley, J. B. 1989. 'DECONSTRUCTING THE MAP'. Cartographica: The International Journal for Geographic Information and Geovisualization 26(2):1-20.

Hazen, Helen D., and Leila Harris. 2017. 'Power of Maps : (Counter) Mapping for Conservation'.

Irwin, Alan, and Mike Michael. 2003. Science, Social Theory and Public Knowledge. Maidenhead ; Philadelphia: Open University Press.

Jacobsson, Kerstin. 2015. Urban Grassroots Movements in Central and Eastern Europe. Burlington: Ashgate Pub.

Jankowski, Piotr, and Timothy Nyerges. 2001. 'GIS-Supported Collaborative Decision Making: Results of an Experiment'. Annals of the Association of American Geographers 91(1):48-70.

Jankowski, Piotr, Tomasz Kaczmarek, Zbigniew Zwoliński, Edyta Bąkowska-Waldmann, Cezary Brudka, Michał Czepkiewicz, Łukasz Mikuła, and Marek Młodkowski. 2018. Zastosowanie aplikacji geoankiety i geodyskusji w partycypacyjnym planowaniu przestrzennym: dobre praktyki. Poznań: Bogucki Wydawnictwo Naukowe.

Kidd, Dorothy. 2019. 'Extra-Activism: Counter-Mapping and Data Justice'. Information, Communication \& Society 22(7):954-70.

Kopeć, Jarosław, Jakub Chełmiński, and Katarzyna Korzeniowska. 2019. 'Warszawska Mapa Miejskich Kopciuchów. Wiemy, Kiedy Przestaną Dymić'. Biqdata.Pl, January 4.

Kowalewski, Maciej, and Zakład Wydawniczy Nomos. 2016. Protest miejski: przestrzenie, tożsamości i praktyki niezadowolonych obywateli miast. Kraków: Nomos.

Lampoltshammer, Thomas J., Scholz, Johannes. 2016. Gubrium, Aline. 2016. 'Citizen-Driven Geographic Information Science’. Pp. 231-45 in Participatory Visual and Digital Research in Action, edited by A. Gubrium. 1st ed. Routledge.

Lidskog, Rolf, and Göran Sundqvist. 2018. 'Environmental Expertise as Group Belonging'. Nature and Culture 13(3):309-31.

MacEachren, A. M., and D. R. F. Taylor. 2013. Visualization in Modern Cartography. Kent: Elsevier Science.

McCormick, Sabrina. 2007. 'Democratizing Science Movements: A New Framework for 
Mobilization and Contestation'. Social Studies of Science 37(4):609-23.

Maharawal, Manissa M. and Erin McElroy. 2018. 'The Anti-Eviction Mapping Project: Counter Mapping and Oral History Toward Bay Area Housing Justice'. Annals of the American Association of Geographers 108(2): 380-389.

Mergler, Lech, Kacper Pobłocki, and Maciej Wudarski. 2013. Anty-bezradnik przestrzenny: prawo do miasta $w$ działaniu. Warszawa: Biblioteka Res Publiki Nowej.

Miasto jest Nasze. 2018. 'Mapa Kopciuchów Miejskich'.

National Environmental Policy 2030 (NEP 2030). 2018. Warsaw: The Ministry of Environment

Niksic, Matej., Michele. Campagna, Pierangelo. Massa, Matteo. Caglioni, and Thomas Theis. Nielsen. 2017. 'Opportunities for Volunteered Geographic Information Use in Spatial Planning'. Retrieved (https://www.ubiquitypress.com/site/chapters/10.5334/bbf.n/download/918/).

Nyerges, Timothy, Piotr Jankowski, David Tuthill, and Kevin Ramsey. 2006. 'Collaborative Water Resource Decision Support: Results of a Field Experiment'. Annals of the Association of American Geographers 96(4):699-725.

Offe, Claus. 1985. New Social Movements : Challenging the Boundaries of Institutional Politics. New York: Graduate Faculty of Political and Social Science, New School for Social Research.

PAP. 2019. 'Wiceprezydent Warszawy: Wymiana Pieców w Lokalach Komunalnych Do Końca 2019 r.' Portal Samorządowy, February 14.

Pawłowska, Krystyna. 2010. 'Partycypacja społeczna w podejmowaniu decyzji dotyczących przyrody w mieście’. Pp. 51-73 in Zrównoważony Rozwój-Zastosowania, edited by T. Bergier, J. Kronenberg. Kraków: Fundacja Sendzimira.

Peluso, Nancy Lee. 1995. 'Whose woods are these? Counter-mapping forest territories in Kalimantan, Indonesia'. Antipode 27(4):383-406.

Pfeffer, Karin, Javier Martinez, David O’Sullivan, and Dianne Scott. 2015. 'Geo-Technologies for Spatial Knowledge: Challenges for Inclusive and Sustainable Urban Development'. Pp. 147-73 in Geographies of Urban Governance: Advanced Theories, Methods and Practices, edited by J. Gupta, K. Pfeffer, H. Verrest, and M. Ros-Tonen. Cham: Springer International Publishing.

Pickvance, Chris. 2003. 'From Urban Social Movements to Urban Movements: A Review and Introduction to a Symposium on Urban Movements'. International Journal of Urban and Regional Research 27(1):102-9.

Pluciński, Przemysław, and Marek Nowak. 2017. 'E Pluribus Unum? Źródła i Specyfika Ruchów Miejskich We Współczesnej Polsce’. Przegląd Socjologiczny 66(3):115-35.

Polish National Strategy for Adaptation to Climate Change (NAS 2020) with the perspective by 2030. 2013. Warsaw: The Ministry of Environment

Putkowska-Smoter, Renata. 2020. 'Greening Urban Politics: Conflicts Over Tree Felling in Warsaw.' Pp. 319-36 in Inequality and Uncertainty, edited by M. Smagacz-Poziemska, M. V. Gómez, P. Pereira, L. Guarino, S. Kurtenbach, and J. J. Villalón. Singapore: Springer Singapore.

Rattray, Nicholas. 2015. Counter-Mapping as Situated Knowledge: Integrating Lay Expertise. Pp. 131 - 146. In Participatory Geographic Research in Participatory 
Visual and Digital Research in Action, edited by Gubrium, Aline, Krista Harper, and Marty Otañez. Walnut Creek: Left Coast Press.

Renzi, Alessandra and Ganaele Langlois. 2015. 'Data Activism'. Pp. 202-225 in Compromised Data From Social Media to Big Data, edited by Langlois, Ganaele, Joanna Redden, and Greg Elmer.

Rieder, Bernhard. 2013. 'Studying Facebook via Data Extraction: The Netvizz Application'. Pp. 346-355 in Proceedings of the 5th Annual ACM Web Science Conference, WebSci '13. New York, NY, USA: ACM.

Rocío, Valderrama-Hernández, Noelia Melero, and Emilio Lucio-Villegas. 2013. Social Mapping: A Tool for a Participatory Construction of the City.

Rosol, Marit, Vincent Béal, and Samuel Mössner. 2017. 'Greenest Cities? The (Post-) Politics of New Urban Environmental Regimes'. Environment and Planning A: Economy and Space 49(8):1710-18.

Sandberg, L. Anders, Adrina Bardekjian, and Sadia Butt, eds. 2015. Urban Forests, Trees, and Greenspace: A Political Ecology Perspective. London ; New York: Routledge, Taylor \& Francis Group, Earthscan from Routledge.

Sieber, Renee. 2006. 'Public Participation Geographic Information Systems: A Literature Review and Framework'. Annals of the Association of American Geographers 96(3):491-507.

Siemiński, Waldemar, Bida-Wawryniuk, Zofia. 2016. 'Konflikty społeczno-przestrzenne w Warszawie w latach 2013-2014’. Człowiek i Środowisko 40(2): 5-28.

Simão, Ana, Paul J. Densham, and Mordechai (Muki) Haklay. 2009. 'Web-Based GIS for Collaborative Planning and Public Participation: An Application to the Strategic Planning of Wind Farm Sites'. Journal of Environmental Management 90(6):202740.

Skawiński Alarm Smogowy. 2017. 'Pytacie Nas, Czy Będziemy Publikować Zdjęcia Kopcących Domów z Naszej Gminy...' Retrieved (https://www.facebook.com/ SkawinskiAlarmSmogowy/photos/a.641534752693272/799159620264117/?type $=3$ \& theater).

Syngellakis, Stavros, Kharen Pinilla, Birgit Hoinle, Anna Mahecha-Groot, and Juliana Cepeda-Valencia. 2018. 'Mapping the Agrodiversity in Bogotá - the Platform Mapeo Agroecobogotá. International Journal of Design \& Nature and Ecodynamics. 13(4): 407-414.

Szulecka, Julia, and Kacper Szulecki. 2017. 'Polish Environmental Movement 19802017: (De)Legitimization, Politics \& Ecological Crises'. SSRN Electronic Journal.

Tahvilzadeh, Nazem, Stig Montin, and Mikael Cullberg. 2017. 'Functions of Sustainability: Exploring What Urban Sustainability Policy Discourse "Does" in the Gothenburg Metropolitan Area'. Local Environment 22(sup1):66-85.

Taylor, Katie Headrick. Counter-Mapping the Neighborhood: A Social Design Experiment for Spatial Justice. 2013. <http://etd.library.vanderbilt.edu/available/etd06142013-141535/>.

Turner, Andrew. 2006. Introduction to Neogeography. Sebastopol, Calif.: O’Reilly.

Wilson, Japhy, and Erik Swyngedouw, eds. 2015. The Post-Political and Its Discontents: Space of Depoliticisation, Spectres of Radical Politics. Paperback edition. Edin- 
burgh: Edinburgh University Press.

Woźny, Piotr. 2019. ‘Był taki kawałek- „Strzelaj albo emigruj”.' Retrieved 9 December 2019 (https://twitter.com/Wozny3).

Zarządzanie zielenia miejska. Informacje o wynikach kontroli. 2017. Warszawa: Najwyższa Izba Kontroli.

\section{BIOGRAPHICAL NOTE}

Renata Putkowska-Smoter is researcher at the IFiS PAN. She is interested in ambiguity and ambivalence towards nature and environmental protection and how they influence to conflicts, governance and politics at local and national level.

Jan Frankowski is researcher at the IFiS PAN and analyst at the Institute for Structural Research. His interests cover opportunities and risks of the energy transition for households, cities, and regions.

OPEN ACCESS: This article is distributed under the terms of the Creative Commons Attribution Non-commercial License (CC BY-NC 4.0) which permits any non-commercial use, and reproduction in any medium, provided the original author(s) and source are credited.

ARTICLE HISTORY: Received 2020-01-09 / Accepted 2020-04-26 